\title{
Dimensional Structure of Satisfaction with Hotel Services
}

\author{
Mladen Mitrović \\ PhD student, University of Primorska, \\ Faculty of Tourism Studies - Turistica, Slovenia \\ mladen.mitrovic@live.com
}

In the promotion and development of services provided by hotels, satisfaction surveys and assessment of the importance of different aspects of hotel services by visitors have an immense importance. Therefore, the aim of this research was to determine which aspects of the hotel are important (in a sample of respondents from Serbia), as well as to determine the dimensional structure of their satisfaction. The sample consists of 200 respondents, visitors to the hotel from the territory of Serbia. In the pilot study, an open-ended questionnaire was constructed for research purposes. Based on the respondents' answers, two scales, which relate to the satisfaction and importance of hotel services, were constructed in the second phase. The number of facets in the scale is 21 , and both constructed scales have good internal reliability. The results showed that the most important aspects of hotel services are safety, responsiveness, price, privacy and the physical characteristics of the hotel. Also, the results of exploratory factor analysis indicate that satisfaction with hotel services in Serbia can be seen as a one-dimensional construct rather than a phenomenon consisting of several different factors. There were no significant differences between the perceived importance of services and satisfaction with hotel services.

Keywords: hotel services, satisfaction, importance, dimensional structure https://doi.org/10.26493/2335-4194.10.57-68

\section{Introduction}

From their outset to this day, hotel companies have had a clear mission about their business direction. Absolute satisfaction of all customer needs has brought an increase in profits, as well as leverage over the competition in the tourism market (Unković \& Zečević, 2009). Therefore, the growing engagement in improving hotel performances through increasing service quality in both practical and theoretical aspects is not surprising at all. Staying in a hotel is no longer just a matter of prestige, but, with its facilities, it has influenced many to consider it as a very important part of their everyday life. The rising number of new hotels, as well as the introduction and development of online booking systems, provided the potential guests with the opportunity to take into consideration even the smallest details when choosing a hotel to stay in. Therefore, hotels pay more attention to public opinion polls, and allocate significant funds for this purpose (Unković \& Zečević, 2009). This study aims to make its own contribution to the research of service quality in hotels. In addition to the theoretical framework, it will show the process of preparing a questionnaire that leads to very important information on guest satisfaction with the hotel services, and which can be of significant help to hotel companies in their surveys.

Therefore, in view of the actuality and significance 
of testing the satisfaction of guests with hotel services, the main problem of this study is finding and determining certain hotel services that are most important for the respondents from Serbia, as well as determining the dimensional structure of satisfaction with these services. The corresponding goals given in the methodological section were formulated based on the research problem. The main idea was to conduct the study in two stages: The first one in which the questionnaire will be constructed based on the answers of the respondents, and the other in which the dimensional structure of the instrument will be checked. That is, a pilot study was first done to determine which aspects of the hotel are important to the guests of the hotel. It can be noted that quantitative scientific research in this region in Serbia is not common, and this work can also serve as the starting point for future research.

\section{Literature Review}

In everyday communication, quality is a frequently mentioned term. In visual terms, the concept of quality is expressed relatively easily, but it is very hard to give a universal definition of it, which means that, in the process of defining it, one must take into account the specific business conditions typical for each individual organization (Barjaktarović, 2013).

According to the interesting definition of service quality in the hotel industry given by Avelini Holje$\operatorname{vac}$ (2002), quality is considered as achievement of established standards and their constant maintenance. Defining quality must be governed by customer demands. Numerous definitions of quality, which can be found in domestic, as well as in international literature, are in favor of this view. A product quality is a measure of its usefulness or suitability to meet customer demands. It is not always clear what is meant by quality, but it is obvious that it can be defined very subjectively. According to some, it is possible to measure quality objectively, according to others, it is a subjective experience (Ćosić, 2013). In whatever way we define quality, one thing is certain - for customers, the only acceptable quality is the one that is in line with their expectations (Parasuraman, Zeithaml, \& Berry, 1988, according to Swarbrooke \& Horner, 2007).
Dealing with the service quality in the hospitality industry has been a subject of interest for numerous authors. Saunders and Graham (1992), point out that 'the intangible nature of the service as a product means that it could be very difficult to place quantifiable terms on the features that contribute to the quality of the product.' The problems in measuring the quality can also arise from the uncertainty which a customer brings, because his or her requirements about the acceptable level of the service could be complicated to determine. O'Neill, Watson, and McKenna (1994), use a term of total quality management, which means that 'quality awareness and practices extend to all aspects of an organization's activities, and are not restricted to identifying and rejecting unacceptable products or services, as was once the situation.' According to them, the main objective of this philosophy is to reach the customer's satisfaction, simultaneously with the achievement of the company's success. Mei, Dean, and White (1999), consider that 'services are gaining increasing importance in today's changing global environment, where many businesses are facing intensifying competition and rapid deregulation, and in order to achieve competitive advantage and efficiency, businesses have to seek profitable ways to stand out.'

$\mathrm{Su}$ (2004), suggests that 'one of the biggest contemporary challenges of management in service industries is providing and maintaining customer satisfaction.' For the author, service quality and customer satisfaction are the key factors in competitive differentiation and customer retention, which suggests that there must be an obligation for hotels to provide a quality service to their customers if they want their business to succeed. Nadiri and Hussain (2005), agree with the previous statement, and point out that, 'in a highly competitive hotel industry, individual hoteliers must find ways to make their products and services stand out among the others.' To achieve this, hoteliers must understand their customers' needs - and then set out to meet (or exceed) these needs. Uran Maravić, Ivankovič, Jerman, and Planinc (2014), emphasize the nature of the hospitality industry, where products are produced and consumed simultaneously, and the direct contact between employees and con- 
sumers that inevitably leads to errors, thus preventing the achievement of high quality standards. The last, and maybe the most important phase in the hotel quality management system, is the information from the customer about their satisfaction with the hotel services. These authors consider that, although many instruments are provided for determining customers' satisfaction, most of them are robust and impractical for everyday use.

Quality is a value which permeates all spheres of modern economic and social life. It is an unavoidable term in the theory and practice of modern management, organization, education and operations of all economic subjects. As a key component of the value of products or services, nowadays, quality represents the most significant characteristic, and one of the strongest assets of every company competing in the international market.

The focus areas for organizations are also changing from profit maximization to maximizing profits through increased customer satisfaction. The pressures of competition are forcing the organizations not only to look at the processes, but also to the way they are delivered (Seth, Deshmukh, \& Vrat, 2005). Only companies that are focused on quality, and thus focused on the satisfaction of their guests, can be successful in the demanding tourism market (Vrtiprah \& Sladoljev, 2012).

Quality in tourism needs to be observed from the perspective of consumers, because customer pleasure and satisfaction are the only true measures of the quality of tourism services. From the customers' point of view, quality depends primarily on their expectations. They will expect to receive the best possible quality for their money, that is, the highest value (value for money). It is assumed that their expectations are realistic, which gives customers an awareness of the difference in the level of service quality offered by, for example, three-star and five-star hotels. Tourists, as consumers, will be thrilled if perceived quality exceeds their expectations. However, they are likely to be disappointed if the quality of some of the services is below their expectations, which can lead to dissatisfaction, even if other services during the trip have been very satisfactory.

\section{Customer Satisfaction Measurement in the Hotel Industry}

The methods for measuring customer satisfaction can be divided into: Indirect method, based on the use of certain indicators which enable connecting the operating results in terms of customer satisfaction; and direct method, that involves the active participation of customers who pronounce upon the level of their satisfaction with the particular service (Angelini, 2005). In order to get the most accurate data possible, various models and techniques for measuring customer satisfaction, which are related to these methods, were developed in the USA and Europe. Each of them has its advantages as well as shortcomings. Thus, several measuring techniques are often employed simultaneously in order to get as objective a picture as possible of customers' perceptions regarding the products or services separately, but also in relation to the competition (Angelini, 2005).

Sales revenues are the first indicators of customer satisfaction, which are used in indirect methods (Angelini, 2005). The analysis of these indicators provides basic information, which must be complemented with the information about consumers and competition.

The analysis of complaints is another technique related to the indirect method for measuring customer (dis)satisfaction (Yuksel, Kilinc, \& Yuksel, 2006). The complaint is a form of communication between the customers and the company through which the customers express dissatisfaction with a particular service and ways of its provision. The analysis of the number and motives of dissatisfied customers contributes to measuring customer satisfaction. It is important to emphasize that a small number of dissatisfied consumers file complaints. Others, who do not inform the company about their dissatisfaction, express their dissatisfaction to others, thus creating a negative image, which can be extremely harmful to the company. The same happens when there is no proper response to a filed complaint. For these reasons, it is necessary first, to stimulate customers to file a complaint if they are dissatisfied, and then to troubleshoot the problem and customers' dissatisfaction timely and adequately.

Gathering and analysis of comments is done in or- 
der to collect information on customers' impressions about certain products or services. The most commonly used are the forms or questionnaires containing several important questions related to customer satisfaction with certain services. When drafting a questionnaire (comment cards) it is necessary to simplify the method of filling in (by circling the answer, giving estimates from 1 to 5 , etc.) in order to include as many customers as possible. These forms are anonymous, which is another important aspect of stimulating customers. When drafting questions, management focuses mainly on aspects of the offer which are considered to be relevant or their strength. Therefore, it is necessary to leave space for a comment so that the customers could express their observations.

Customer Retention Index is a very useful technique for measuring customer satisfaction (Jankal, 2003). It expresses the number of consumers who have remained loyal to the end of the year, compared to those that existed at the beginning of the year and the new consumers. This indicator is also used to determine the company's ability to retain customers. A satisfied customer is not a guarantee that he/she will return to the same hotel; it is necessary to establish a long-term relationship with customers and to ensure their loyalty (Sekulić \& Mandarić, 2013). In applying this technique, one should take into account the fact that a loyal customer is not necessarily a satisfied one, but might actually be the result of the lack of better alternatives, cost increase in case of a change, etc. Also, this index does not reveal whether the 'lost customers' left for better offers or out of curiosity to try something new (Jankal, 2003).

Based on the analysis of techniques which are related to the indirect method, it can be concluded that not one of these techniques is enough by itself to get the overall picture of customer satisfaction, and that they should be combined with techniques which involve the customer directly. The following techniques can be singled out as the best known and the most used ones related to the direct method (Angelini, 2005): Critical Incident Technique, Problem Detection System, Profit Impact of Market Strategy (PIMs), Customer Satisfaction Survey, The Kano model, Blueprinting, the SERVQUAL method.
Critical Incident Technique is based on the assumption that customer satisfaction with a product or service is the result of the so-called 'critical incidents' (Gremler, 2004). This method assumes the existence of a 'tolerance zone', in other words, a customer will not notice a slight discrepancy between their perceived experience and their expectations. Critical incidents are those that go beyond the tolerance zone, and those are the incidents that can be described in detail and which deviate, either in a positive or a negative way, from what is usual or expected. This technique implies raising three key issues relating to these incidents (Gremler, 2004). What incidents in the process of delivering and using a service caused a positive or a negative feeling? When did it happen? What circumstances contributed to the fact that these incidents are considered critical?

The customer is asked simple questions that require adetailed description of the incident. Based on the obtained information, the reasons that led to that particular satisfaction or dissatisfaction are determined, that is, the elements of service are defined that should be improved in order to enhance customer satisfaction.

Problem Detection System is a technique based on the detection of the problems that customers face when using a service (Swarbrooke \& Horner, 2007). After detecting a problem, the level of importance, attributed to it by customers themselves, is determined in order to estimate the extent to which this particular problem influences behavior when purchasing and using the service.

Profit Impact of Market Strategy (PIMs) is a technique that is based on the program of competitive strategies research (Angelini, 2005). It was developed with the aim of determining how the key elements of a strategy affect revenue and business growth. It pointed out the relationship between the company revenue and the quality of services it provides. A company that manages to offer a service of better quality than its competition will have a short-term advantage in terms of higher profits, and a long-term advantage in terms of taking up a larger part of the market.

Customer Satisfaction Survey is a technique that aims to measure periodically the degree of customer 
satisfaction and to elaborate the indicators of service quality, making comparisons over time (Angelini, 2005). Its use is important for the companies that want to compare the results after the implementation of some actions taken to improve service quality, and, at the same time, are well acquainted with the needs of customers.

The Kano model is named after its creator, Professor Noriaki Kanu from the Tokyo University of Science (Kano, Seraku, Takahashi, \&, Tsuji 1984, according to Chen \& Chuang, 2008). Through this model he attempted to assess the degree of customer satisfaction based on the unexpected service qualities. He identifies the qualities of the three main categories of services whose presence influences customer satisfaction: The basic or expected qualities, articulated qualities, and surprising or qualities that delight. These qualities can be interpreted as customer requirements: Basic requirements, expected requirements and unexpected requirements (exciting/surprising experience) (Chen \& Chuang, 2008). Basic requirements are related to the qualities that the product/service must possess according to the expectations of customers, that is, the qualities that are taken for granted. The expected requirements are based on the principle that customer satisfaction is proportional to the functionality of a product/service performance. The unexpected requirements (exciting/surprising experience) are the factors that should surprise and delight the customer, the factors that are not expected from the product/service.

This model also has a time dimension of curves (Chen \& Chuang, 2008). If, at one point in time, something was attractive (e.g. during the 1980s arrangements were presented only verbally, without any special multimedia information), it becomes expected later on. The attractiveness that is now offered on the market, after some time, becomes the object of imitation by competitors and, thus, becomes expected in future models of the product or service. Another dimension of the Kano model applies to the market segment as well. If, in one segment, something is attractive, that does not mean that it will also be in another, because it is expected or basic there. Social norms and rituals of consumption influence consumers' expectations and their behavior greatly when purchasing products and services (Angelini, 2005).

Blueprinting is a model which consists of process preparation so that the service could be defined as a systematic process in chronological order (Williams \& Buswell, 2003) that follows the sequence from detecting to solving problems related to product quality. It enables the production and delivery to be put into the context of the amount of engagement required from the employees and customers. This technique is used in the tourism industry (hotels and restaurants), where it is known as the 'Service Factory', due to the inseparability of service production and consumption (Williams \& Buswell, 2003). It connects customer satisfaction and the system of service delivery well.

The SERVQUAL model is one of the most commonly used techniques for determining customer satisfaction with service quality in relation to their expectations. Parasuraman, Zeithaml and Berry (Parasuraman et al., 1988, according to Swarbrooke \& Horner, 2007), developed a technique for measuring service quality known as SERVQUAL. They define service quality as the perception of the specificities of the quality of hospitality companies, which is based on the comparison between the performances that were delivered to a customer by a particular company and general customer expectations that are the same for all companies that provide the same services. The SERVQUAL model is used by hospitality companies so they can understand the expectations and perceptions of their customers more easily.

\section{Method}

The survey approach was used to conduct the present research. The problem of this study was to identify the underlying structure of the Serbian sample. The aim of the research was to determine the dimensional structure of satisfaction with hotel services on a sample from Serbia, and to determine which aspects of hotel services were considered the most important by the respondents.

The research questions read:

1. What aspects of hotel services are the most important for respondents from Serbia? 
2. Is satisfaction with hotel services a one-dimensional or multidimensional construct on a sample of respondents from Serbia?

The survey was conducted in two stages, and the sample was suitable, and consisted of a total of 200 respondents. A pilot study was conducted to determine which aspects of hotel service are important for guest satisfaction.

\section{The First Stage}

The sample was convenient and it consisted of 100 examinees of both sexes ( 58 females and 42 males), aged 18 to 70 years, mean age 34.3 years. The survey was anonymous. The task of each respondent was to specify those aspects of hotel services which, in their opinion, affect their satisfaction with hotel services. Aquestionnaire with open questions was used in this pilot survey. The answers were stored in a database, and the frequencies were calculated for each of the responses. Those answers whose frequency exceeded 10 were retained in the survey, i.e., the responses that were appearing in $10 \%$ and over of the total sample of the respondents. They are displayed in Table 1. The criterion for determining the boundaries for selecting the response was the frequency of occurrence of certain characteristics, since all the following different answers (hotel aspects) appeared in a significantly smaller number, mostly in 5 subjects.

\section{The Second Stage}

Based on the results of the pilot study, a questionnaire of 21 items was designed that cover different aspects of satisfaction with hotel services. The survey was anonymous, and the task of respondents was to assess, on a 5-point Likert scale, each of the listed aspects according to their importance in assessing hotel services, as well as to estimate the level of their satisfaction with that kind of service, taking into account the latest hotel where they had stayed. The sample was suitable and it comprised 100 respondents of both sexes (46 males and 56 females), aged $18-74$ years, mean age 39.6 years. The sample was collected by random selection near different hotels in several cities in Serbia. Respondents were asked to participate in an anonymous survey to be used for scientific purposes? Exploratory fac-
Table 1 Aspects of Hotel Services Which Affect Satisfaction with Hotel Services

1. Security at the hotel
2. Service promptness
3. Price
4. Discretion
5. Hotel interior
6. Hotel exterior
7. Hotel cleanliness
8. Air conditioning well resolved
9. Respect for house rules
10. Food quality
11. Staff courtesy
12. Hotel location
13. Access to medical services
14. Comfort of rooms
15. Hotel parking lot
16. Regular changing of bed linens
17. Existence of facilities
18. Staff professionalism
19. The room has a balcony
20. Road communication with the hotel
21. Overall service quality
Satisfaction
Importance
Scale

tor analysis (principal components analysis) of the obtained data was then conducted to determine whether the satisfaction with hotel services on a sample from Serbia was a one-dimensional structure or it consisted of several dimensions. The same was done with the information concerning the importance of certain hotel services. Both scales showed good internal consistency reliability, Cronbach's Alpha > 0.7 (Table 2).

\section{Results}

When it comes to the satisfaction with hotel services, the results of principal components analysis revealed 
Table 3 Satisfaction Scale: Total Variance Explained

\begin{tabular}{|c|c|c|c|}
\hline \multirow[t]{2}{*}{ Component } & \multicolumn{3}{|c|}{ Initial Eigenvalues } \\
\hline & (1) & (2) & (3) \\
\hline 1 & 9.405 & 44.786 & 44.786 \\
\hline 2 & 1.432 & 6.821 & 51.607 \\
\hline 3 & 1.253 & 5.965 & 57.572 \\
\hline 4 & 1.083 & 5.158 & 62.730 \\
\hline 5 & 0.953 & 4.540 & 67.270 \\
\hline 6 & 0.896 & 4.267 & 71.537 \\
\hline 7 & 0.832 & $3 \cdot 961$ & 75.499 \\
\hline 8 & 0.802 & 3.821 & $79 \cdot 319$ \\
\hline 9 & 0.650 & 3.095 & 82.415 \\
\hline 10 & 0.595 & 2.835 & 85.250 \\
\hline 11 & 0.566 & 2.693 & 87.943 \\
\hline 12 & 0.498 & 2.370 & 90.313 \\
\hline 13 & 0.392 & 1.865 & 92.178 \\
\hline 14 & 0.345 & 1.645 & 93.822 \\
\hline 15 & 0.281 & 1.340 & 95.162 \\
\hline 16 & 0.268 & 1.276 & 96.438 \\
\hline 17 & 0.202 & 0.963 & 97.401 \\
\hline 18 & 0.176 & 0.838 & 98.240 \\
\hline 19 & 0.150 & 0.712 & 98.952 \\
\hline 20 & 0.138 & 0.657 & 99.609 \\
\hline 21 & 0.082 & 0.391 & 100.000 \\
\hline
\end{tabular}

Notes (1) total, (2) percentage of variance, (3) cumulative percentage.

as presented in Table 3 . The results show that, according to the Guttman-Kaiser criterion, 4 factors can be extracted that explain $62.73 \%$ of the variance. If we take into account the screen criterion, we see that one factor can be extracted that explains $44.78 \%$ of the variance. In support of this solution, speaks the matrix of the structure, which shows that almost all of the items have a high saturation on the first factor (Table 4).

Such a solution is reached even after the implementation of different rotations.

Based on the results of the exploratory factor analysis, it can be concluded that the structure of satisfaction with hotel services in Serbia is one-dimensional, and that we can talk about general satisfaction with
Table 4 Component Matrix of the Satisfaction scale

\begin{tabular}{|c|c|c|c|c|}
\hline & 1 & 2 & 3 & 4 \\
\hline 1 & 0.754 & -0.048 & -0.210 & -0.184 \\
\hline 2 & 0.713 & -0.236 & -0.330 & -0.170 \\
\hline 3 & 0.744 & -0.177 & -0.173 & -0.229 \\
\hline 4 & 0.700 & -0.324 & -0.144 & 0.066 \\
\hline 5 & 0.680 & -0.410 & 0.204 & 0.016 \\
\hline 6 & 0.751 & -0.232 & 0.001 & 0.190 \\
\hline 7 & 0.771 & 0.128 & -0.158 & 0.141 \\
\hline 8 & 0.759 & -0.370 & -0.131 & 0.166 \\
\hline 9 & 0.593 & 0.086 & -0.179 & 0.529 \\
\hline 10 & 0.685 & 0.272 & -0.083 & 0.329 \\
\hline 11 & 0.697 & 0.363 & -0.151 & -0.105 \\
\hline 12 & 0.656 & 0.481 & 0.103 & -0.116 \\
\hline 13 & 0.736 & 0.048 & 0.044 & -0.254 \\
\hline 14 & 0.665 & 0.047 & 0.069 & -0.152 \\
\hline 15 & 0.547 & 0.076 & 0.164 & 0.207 \\
\hline 16 & 0.247 & 0.142 & 0.421 & 0.466 \\
\hline 17 & 0.564 & -0.341 & 0.444 & 0.060 \\
\hline 18 & 0.728 & 0.124 & -0.196 & -0.060 \\
\hline 19 & 0.453 & -0.154 & 0.613 & -0.260 \\
\hline 20 & 0.609 & 0.439 & 0.218 & -0.127 \\
\hline 21 & 0.764 & 0.202 & 0.151 & -0.169 \\
\hline
\end{tabular}

hotel services as a single dimension rather than a phenomenon which is estimated structurally by a number of factors.

After this, the measures of descriptive statistics were calculated for the issues concerning the importance of hotel services. The results showed that all these aspects of the satisfaction with hotel services were assessed as equally important to the sample from Serbia. The aspects that were estimated the least important for the satisfaction with hotel services were hotel parking lot, whether a room had a balcony or not, and whether there were facilities such as gym, animators, etc. while hotel cleanliness, security at the hotel, and courtesy and friendliness of staff were ranked as the most important aspects of the satisfaction with hotel services among Serbian customers (Table 5).

In order to check whether the satisfaction with ho- 
Table 5 Descriptive Statistics for the Importance Scale

\begin{tabular}{lrr}
\hline Aspects of hotel service & $(1)$ & $(2)$ \\
\hline Hotel cleanliness & 4.62 & 0.80 \\
Security at the hotel & 4.59 & 0.81 \\
Staff courtesy & 4.46 & 0.86 \\
Air conditioning well resolved & 4.45 & 0.98 \\
Food quality & 4.44 & 0.87 \\
Service promptness & 4.43 & 0.84 \\
Price & 4.40 & 1.00 \\
Overall service quality & 4.37 & 0.88 \\
Regular changing of bed linens & 4.34 & 1.00 \\
Comfort of rooms & 4.34 & 0.88 \\
Discretion & 4.30 & 1.02 \\
Hotel interior & 4.21 & 0.99 \\
Hotel location & 4.16 & 0.86 \\
Hotel exterior & 4.15 & 0.96 \\
Staff professionalism & 4.14 & 1.02 \\
Respect for house rules & 4.13 & 1.09 \\
Road communication with the hotel & 4.11 & 0.90 \\
Access to medical services & 4.04 & 1.11 \\
Existence of facilities & 3.90 & 1.03 \\
Hotel parking lot & 3.87 & 1.13 \\
The room has a balcony & 3.86 & 1.24 \\
\hline Notes (1) & & \\
\hline
\end{tabular}

Notes (1) mean, (2) standard deviation.

tel services is a truly unique dimension, different from other dimensions of hotel services' assessment, principal components analysis was conducted of the items related to the satisfaction with hotel services and the evaluation of the importance of these services (Table 6).

The results show that, based on the scree criterion, two factors can be extracted explaining the total of $51 \%$ of the variance.

If we look at the matrix of the structure, we can see that the answers related to the satisfaction with hotel services are grouped consistently on the second, and the responses related to the assessment of the importance of these aspects of hotel services are grouped on the first factor (Table 7). Thus, out of all 42 items that were subject to factor analysis, the top 21 satisfaction
Table 6 Importance Scale: Total Variance Explained

\begin{tabular}{lrrr}
\hline Component & \multicolumn{3}{c}{ Initial Eigenvalues } \\
\cline { 2 - 4 } & $(1)$ & $(2)$ & $(3)$ \\
\hline 1 & 12.785 & 30.441 & 30.441 \\
2 & 8.640 & 20.570 & 51.012 \\
3 & 2.131 & 5.073 & 56.085 \\
4 & 1.791 & 4.265 & 60.350 \\
5 & 1.314 & 3.128 & 63.478 \\
6 & 1.237 & 2.944 & 66.422 \\
7 & 1.173 & 2.792 & 69.214 \\
8 & 1.077 & 2.564 & 71.778 \\
9 & 1.017 & 2.421 & 74.199 \\
\hline
\end{tabular}

Notes (1) total, (2) percentage of variance, (3) cumulative percentage.

with hotel services gave the largest saturation to the second factor, while the other 21 items gave the largest saturation to the first factor. Therefore, the second factor can be called satisfaction with hotel services, and the first assessment of the importance of these services.

This shows that there are two dimensions to this questionnaire, as well as that the satisfaction with hotel services in Serbia can be viewed as a single dimension.

For descriptive purposes, a $t$-test for dependent samples was conducted, and it is shown in Table 8. This statistical technique was used because it compares the arithmetic meanings of a group obtained in two different tests. In our case, we compared the average scores obtained from the satisfaction with hotel services and the assessment of the importance of these services, on a sample of respondents from Serbia.

Results show that there isn't a statistically significant difference between perceived importance of and satisfaction with hotel service. This finding isn't a surprise, considering the fact that people will probably choose to stay in hotels that do have contents that are important for their satisfaction.

\section{Discussion}

The goal of this study was to examine the dimensional structure of hotel service satisfaction on a sample from Serbia, and to determine which aspects of hotel ser- 
Table 7 Component Matrix (Solution with Two Factors)

\begin{tabular}{|c|c|c|c|c|c|}
\hline (a) & (1) & (2) & (b) & (1) & (2) \\
\hline 1 & 0.455 & 0.608 & 1 & 0.738 & -0.176 \\
\hline 2 & 0.431 & 0.571 & 2 & 0.717 & -0.196 \\
\hline 3 & 0.369 & 0.655 & 3 & 0.545 & -0.198 \\
\hline 4 & 0.456 & 0.543 & 4 & 0.717 & -0.187 \\
\hline 5 & 0.441 & 0.522 & 5 & 0.691 & -0.420 \\
\hline 6 & 0.426 & 0.617 & 6 & 0.712 & -0.213 \\
\hline 7 & 0.422 & 0.642 & 7 & 0.759 & -0.287 \\
\hline 8 & 0.498 & 0.577 & 8 & 0.800 & -0.330 \\
\hline 9 & 0.325 & 0.491 & 9 & 0.715 & -0.245 \\
\hline 10 & 0.257 & 0.644 & 10 & 0.646 & -0.501 \\
\hline 11 & 0.405 & 0.567 & 11 & 0.717 & -0.400 \\
\hline 12 & 0.309 & 0.579 & 12 & 0.729 & -0.343 \\
\hline 13 & 0.433 & 0.594 & 13 & 0.712 & -0.336 \\
\hline 14 & 0.389 & 0.546 & 14 & 0.682 & -0.357 \\
\hline 15 & 0.226 & 0.510 & 15 & 0.601 & -0.276 \\
\hline 16 & 0.207 & 0.158 & 16 & 0.717 & -0.417 \\
\hline 17 & 0.186 & 0.549 & 17 & 0.578 & -0.316 \\
\hline 18 & 0.363 & 0.632 & 18 & 0.727 & -0.319 \\
\hline 19 & 0.189 & 0.414 & 19 & 0.443 & -0.255 \\
\hline 20 & 0.271 & 0.550 & 20 & 0.675 & -0.170 \\
\hline 21 & 0.418 & 0.639 & 21 & 0.726 & -0.243 \\
\hline
\end{tabular}

Notes (a) satisfaction scale, (b) importance scale, (1) factor 1: importance, (2) factor 2: satisfaction.

Table 8 Difference between Perceived Importance of and Satisfaction with Hotel Service

\begin{tabular}{rrrrr}
\hline$(1)$ & $(2)$ & $(3)$ & $(4)$ & $(5)$ \\
\hline 0.154 & 0.916 & 1.685 & 99 & 0.095
\end{tabular}

Notes (1) mean, (2) standard deviation, (3) $t$-test for a dependent sample, (4) degrees freedom, (5) significance.

vices were considered the most important by the respondents.

First, on a sample of 100 respondents, in the first phase of the survey, aspects of hotel services which influence the satisfaction of respondents were selected (based on the answers of the respondents). The results showed that the safety of the hotel is in the first place of respondents' answers. In an earlier study in Serbia (Vujko, Vujnić, Gajić \& Petrović, 2015), in the context of an examination of the expected and perceived quality of hotel services, the results also showed that safety is an extremely important feature for acquiring an appropriate picture in the hotel's tourist awareness. According to the authors, trust and security are mirrored in people who are 'a link' between guests and hotels, and it is also the goal of the hotel to build trust and loyalty between contact staff and hotel guests.

This result can be understood in such a way that, regardless of whether guests come to hotels for work or vacation, they certainly do not want to consider whether their personal belongings are safe, whether they will be stolen, etc. So, for hotel management, it is important to provide the feeling that guests are not compromised, which can be accomplished in different ways: By installing special safes into rooms, engaging security, adding security cameras to and around the hotel, editing space around the hotel to look bright and safe.

The second place in frequency in our pilot survey, was the speed and efficiency of hotel services (promptness or responsiveness). Johnston (1995), emphasized that the efficiency of responding to the needs and requirements of hotel guests, the attendance of guests and the response to the problem, and 'unsolicited employee actions', are key aspects that affect both the satisfaction and the discontent of visitors. It could be said that security and responsiveness belong to the 'human factor of hotel services, that is, the quality of employees, within which their abilities, knowledge and skills play a big role, and affect the overall amount of business.

The explanation for this result can also be found in the time spent hosting at the hotel. Usually it is a few days away, a business conference or the like, when waiting for staff, waiting in the lines, for serving food and drinks, for carrying luggage, means losing the precious time that the guests set aside for a pleasurable holiday. Therefore, it is not surprising that the respondents often stated this service as very important.

The third place in the list of factors that affect satisfaction is the price. According to Knežević, Barjaktarović and Obradović (2014), the price is an important factor in the sense that the hotel industry is under constant control and pressure to improve the quality of 
its product continually and, at the same time, optimize price and quality. The price of the hotel product represents the value that the hotel generates through the location, appearance, facilities, service, image and satisfaction of the users of hotel services (Barjaktarović, 2013). The discretion in the hotel, which is the fourth most frequent response, belongs to the already described 'human factor' in the hotel, that is, the discretion the staff guarantees refers to the knowledge and kindness of the staff, which creates the feeling that the company can be trusted (Barjaktarović, 2013).

Then, in the opinion of our respondents from Serbia, the aspects that we can label as physical characteristics of the hotel (hotel interior, exterior, cleanliness, air conditioning, comfort of rooms, ...), Vujko et al. (2015) marked as 'tangible' and explained that, in this context, it implies physically visible things in the process of providing services (such as equipment, interior design and exteriors, uniforms and appearance of staff, promotional material, appearance of rooms, cleanliness), and it was also pointed out that the hotel guests' satisfaction depends largely on them. These authors also stated that the location of the hotel facility, which proved to be important in this research, plays an important role in the satisfaction of guests, as well as the availability of parking spaces, the distance of cultural and historical monuments and, for example, connection with the city center. Based on this result, it is clear that the whole appearance and cleanliness of the interior rooms of the hotel, room, restaurant, or the outside environment, must strive constantly for attractiveness and perfection. This also indicates that, for the marketing of a hotel team, it is important to deal with as many details of different rooms as possible, in order to attract as many tourists as possible, and for hotel managers to keep in mind constantly that the appearance and cleanliness are important aspects in the satisfaction of guests.

In the second phase of the research, the application of factor analysis was aimed at determining whether the satisfaction with hotel services on a sample from Serbia, was a one-dimensional structure or it consisted of several dimensions. The same was done with the information concerning the importance of certain hotel services. In this study, both scales showed good in- ternal consistency reliability. Results show that, on the Serbian sample, it is a one-dimensional phenomenon. We can say that, on the Serbian sample, hotel service satisfaction is perceived as global. It is a unique dimension, not a phenomenon that, in its structure, has more different factors. The results of factor analysis showed that our questionnaire has two substantially different dimensions - satisfaction with hotel service, and importance of hotel service aspects. Different dimensions have been highlighted in some other research on client satisfaction with hotel services. For example, in the research of Parasuraman et al. (1988, according to Swarbrooke \& Horner, 2007), five dimensions were isolated in the analysis: Tangibles, reliability, responsiveness, assurance and empathy, as the basis for their service quality measurement instrument, SERVQUAL. Armistead (1990, according to Johnston, 1995), found two different dimensions of the satisfaction with hotel services: 'Firm' and 'soft.' The firm dimensions are time (responsiveness), fault freeness and flexibility (ability to customize the service or add additional services). The soft dimensions are style (accessibility of staff and ambience), steering (the degree to which customers feel in control of their own destiny) and safety (trust, security).

However, as already mentioned, this is not the case in this survey, as it has been shown that satisfaction with hotel services in Serbia can be seen as a onedimensional construct. In a study by Milfelner, Snoj, and Korda (2009), the one-dimensional structure of satisfaction with hotel services has been confirmed. The authors point out that 'overall assessment of the guest satisfaction and hotel image model provides evidence that the constructs are one-dimensional.' Onedimensional structure sees satisfaction as one variable that represents general satisfaction with services.

In this study, results show that there is no statistically significant difference between perceived importance of and satisfaction with hotel services. This finding isn't a surprise, considering the fact that people will probably choose to stay in hotels that do have contents which are important for their satisfaction. In our study, almost all given aspects are equally important for hotel service satisfaction, where politeness to a customer, hotel cleanliness, security at the hotel stand out slightly 
on the Serbian sample. This result indicates that respondents do not give a noticeable advantage to the human factor of providing services (kindness of staff), or objective characteristics (cleanliness in the hotel), or feel the security that is a subjective construct. All these different aspects are equally important, and it is important for all of them to pay attention to building the image of the hotel and retaining and attracting new guests. What is clear, is that it is certainly important to use techniques within the direct method of measuring customer satisfaction, in order to improve the quality of business and the provision of hotel services. According to Barsky (1992), guest survey techniques in hotels can contribute in different ways and to different parties: Managers can get bonuses, employees can be rewarded or re-qualified, resources can be re-routed, contacts are established and developed, and guests get a way to be respected and give their opinion.

\section{Conclusions}

Measuring the satisfaction of visitors to the hotel is the starting point in the planning and improvement of hotel services, and relationships with guests. Within the methods of measuring satisfaction, research is the most used, for it serves to measure the performance of a hotel facility from the viewpoint of guests' experiences.

The advantage of this study is that it has somewhat illuminated everything that hotel visitors in Serbia consider important when evaluating hotel service, and it gives us an insight into their expectations. Persons who are involved in the improvement of hotel services can also benefit from the knowledge that satisfaction with services here is a unique phenomenon, since it does not consist of several factors, but all the characteristics are important and, grouped together, and should be considered as such.

Here, we can mention that the quantitative research of this area in Serbia is rare, and does not deal mainly with the construction of adequate instruments for measuring the satisfaction of guests. That is why the additional significance of this research is one such attempt, in which we, on the basis of an open-ended question, tried to obtain clear information on which aspects of the hotel are important for the satisfaction of the guests, and on the basis of them, we make an adequate questionnaire. Then, using the appropriate statistical technique, we check the factor structure of the constructed instrument, and explain further the constructs of satisfaction, and the importance of evaluating the aspects of hotel services on the sample of respondents in Serbia. In this way, we wanted to somehow draw attention to the importance of applying research (and appropriate methodology) in the field of tourism.

Through the results, we answered two main research questions. Certain aspects are seen as more significant among respondents from Serbia (security, kindness, purity, speed of service), but all aspects are considered important. A clear dimensional structure has also been obtained, which suggests that satisfaction with hotel services on our sample is a onedimensional construct, and that satisfaction with hotel services and the assessment of the importance of services are two different factors.

What could be improved further, and what is the limit of this research, is to examine the dimensional structure of a larger number of respondents of the Serbian population. Also, to look at the differences in satisfaction with the sociodemographic characteristics of the respondents. Future research in this area can also be focused on searching for some other, more precise aspects of satisfaction with hotel services, which relate primarily to hotel staff, given that it has also been discovered that the human factor of the hotel has a significant role in the assessment by guests in Serbia.

\section{References}

Avelini Holjevac, I. (2002). Upravljanje kvalitetom u turizmu $i$ hotelskoj industriji. Opatija, Croatia: Fakultet za turistički menadžment.

Angelini, A. (2005). Customer relationship management e customer satisfaction. Milan, Italy: Franco Angeli.

Armistead, C. (1990). Service operations strategy: Framework for matching the service operations task and the service delivery system. International Journal of Service Industry Management, 1(2): 6-16.

Barjaktarović, D. (2013). Upravljanje kvalitetom u hotelijer$s t v u$. Belgrade, Serbia: Fakultet za turistički i hotelijerski menadžment.

Barsky, J. D. (1992). Customer satisfaction in the hotel in- 
dustry: Meaning and measurement. Hospitality Research Journal, 16(1), 51-73.

Chen, C. C., \& Chuang, M. C. (2008). Integrating the Kano model into a robust design approach to enhance customer satisfaction with product design. International Journal of Production Economics, 114(2), 667-681.

Ćosić, M. (2013). Menadžment kvaliteta u turizmu. Belgrade, Serbia: Visoka turistička škola strukovnih studija.

Gremler, D. D. (2004). The critical incident technique in service research. Journal of Service Research, 7(1), 65-89.

Jankal, R. (2003). Tri^M - The customer retention system. Journal of Information, Control and Management Systems, 1, 39-46.

Johnston, R. (1995). The determinants of service quality: Satisfiers and dissatisfiers. International Journal of Service Industry Management, 6(5), 53-71.

Kano, N., Seraku, N., Takahashi, F., \& Tsuji, S. (1984). Attractive quality and must-be quality. Hinshitsu, The Journal of the Japanese Society for Quality Control, 14(2), 39-48.

Knežević, M., Barjaktarović, D., \& Obradović, P. (2014). Ocenjivanje kvaliteta hotelskih usluga putem interneta. In Sinteza 2014: Impact of internet on business activities in Serbia and worldwide (pp. 767-771). Belgrade, Serbia: Singidunum University.

Mei, A. W. O., Dean, A. M., \& White, C. J. (1999). Analysing service quality in the hospitality industry. Managing Service Quality: An International Journal, 9(2), 136-143.

Milfelner, B., Snoj, B., \& Korda, A. P. (2011). Measurement of perceived quality, perceived value, image, and satisfaction interrelations of hotel services: Comparison of tourists from Slovenia and Italy. Društvena istraživanja, 3(113), 605-624.

Nadiri, H., \& Hussain, K. (2005). Perceptions of service quality in North Cyprus hotels. International Journal of Contemporary Hospitality Management, 17(6), 469-48o.

O’Neill, M., Watson, H., \& McKenna, M. (1994). Service quality in the Northern Ireland hospitality industry. Managing Service Quality: An International Journal, 4(3), 36-40.

Parasuraman, A. P., Zeithaml, V., \& Berry, L. (1988). SERVQUAL: A multiple-item scale for measuring consumer perceptions of service quality. Journal of Retailing, 64(1), 12-40.
Saunders, I. W., \& Graham, M. A. (1992). Total quality management in the hospitality industry. Total Quality Management, 3(3), 243-255.

Sekulić, D., \& Mandarić, M. (2013). Kvalitet usluga kao determinanta satisfakcije potrošača u hotelijerstvu. Marketing, 44(3), 231-246.

Seth, N., Deshmukh, S. G., \& Vrat, P. (2005). Service quality models: A review. International Journal of Quality o Reliability Management, 22(9), 913-949.

$\mathrm{Su}$, A. Y. L. (2004). Customer satisfaction measurement practice in Taiwan hotels. International Journal of Hospitality Management, 23(4), 397-408.

Swarbrooke, J., \& Horner, S. (2007). Consumer behavior in tourism. Oxford: Elsevier.

Unković, S., \& Zečević, B. (2009). Ekonomika turizma. Belgrade, Serbia: Centar za izdavačku delatnost Ekonomskog fakulteta u Beogradu.

Uran Maravić, M., Ivankovič, G., Jerman, M., \& Planinc, T. (2014). An effective customer satisfaction measurement system: Case study of BWP Slon. Paper presented at the conference Dialoguing tourism/5th Encuentros, Portorož, Slovenia, 26-28 September.

Vrtiprah, V., \& Sladoljev, J. (2012). Utjecaj zadovoljstva zaposlenika na kvalitetu proizvoda i usluga u hotelskom poduzeću. Ekonomska misao i praksa, 21(1), 97-122.

Vujko, A., Vujnić, J., Gajić, T., \& Petrović, M. (2016). Quality of services in tourism industry as a model of tourism destination management. Škola biznisa, No. 1, 22-31.

Williams, C., \& Buswell, J. (2003). Service quality in leisure and tourism. Wallingford, England: CA B I.

Yuksel, A., Kilinc, U., \& Yuksel, F. (2006). Cross-national analysis of hotel customers' attitudes toward complaining and their complaining behaviour. Tourism Management, $27(1), 11-24$.

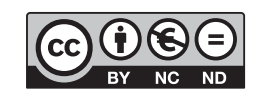

This paper is published under the terms of the Attribution- NonCommercial-NoDerivatives 4.0 International (CC B Y-NC-ND 4.0) License. 